\title{
FINDING FOLK RELIGION: AN ARCHAEOLOGY OF 'STRANGE' BEHAVIOUR
}

\author{
Sonja Hukantaival
}

\begin{abstract}
Archaeology is not only about describing things; we also seek to understand what we find. Sometimes a find can seem puzzling, unexpected in the context in question. It is argued here that evidence of non-Christian elements of religiosity in a historical context can constitute such surprising finds. These finds become less confusing in the light of other sources, such as folklore accounts and historical records. Still, archaeology can offer something not accessible to other disciplines.

This paper discusses the phenomenon of folk religion, and the ways that we can take to find the meanings behind the material remains of practices, which may perhaps seem odd to us. A multidisciplinary approach is favoured, and the contribution of archaeology is crucial in gaining information about past practices. The paper also offers a short survey of some archaeological approaches to questions of folk religion. Another issue addressed is why we might be surprised to find evidence of 'strange' practices in historical contexts. It is suggested here that historical constructs about the 'civilising' effects of Christianity, Reformation, and Enlightenment, respectively, have affected the way that religiosity has been seen in the context of historical Europe.
\end{abstract}

Keywords: folk/popular/vernacular religion, historical archaeology, multidisciplinarity, ritual deposit

\section{INTRODUCTION}

If, for example, an upside-down turned goat skull is found, clearly deliberately deposited at a border-mark (see Fig. 1), archaeologists' interpretations easily turn towards a potentially religious action behind the find. In a prehistoric setting, such a find may be discussed without any unconcealed value-charges, but what if it was found in a historical, Christian, context? The find in question was unearthed during archaeological excavations in the town of Turku (in south-western Finland) in 2006 (Hukantaival 2007: 72; Saloranta 2010: 70). It was dated to the 14th century, and it lay right next to the cathedral; thus it was situated in the middle of the religious centre of the area. 


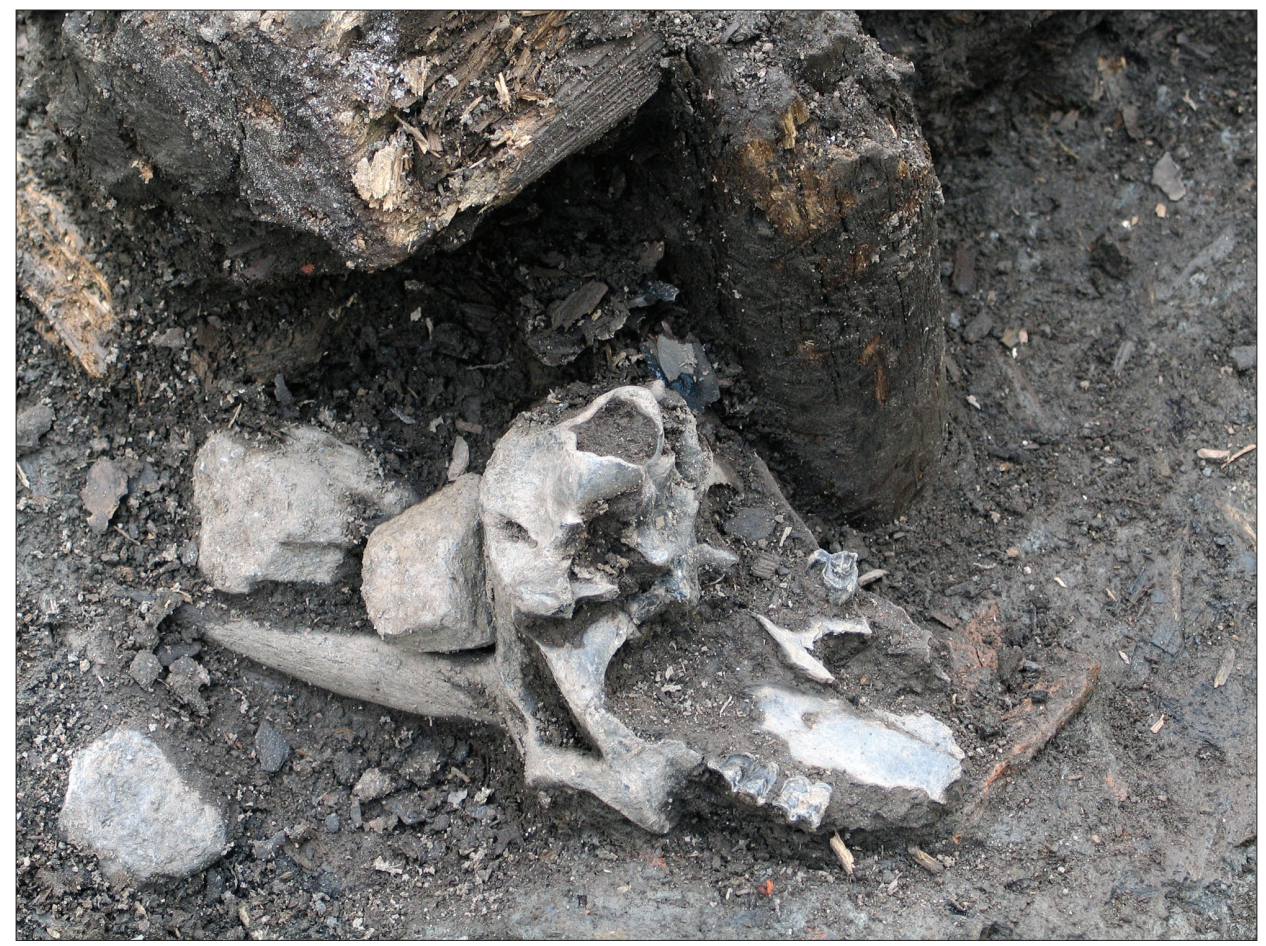

Figure 1. Deposited goat skull at a 14th-century border mark. Photo by Sonja Hukantaival 2006.

As historian Stephen A. Mitchell points out, Western historiography has revealed a tendency to portray the conversion to Christianity in a triumphalist manner, resulting in a complete, uniform, and evenly distributed spiritual hegemony. Any controversial evidence has generally been dismissed out of hand (Mitchell 2011: 38). One can easily suspect that the original reasons behind this conduct have been political, but I suggest that this attitude is still unconsciously with us scholars, even though the importance of the political reasons has diminished.

Many scholarly works offering a general survey of religious matters reveal this aspect. It is perhaps not so surprising that the general surveys offered by archaeologists, who traditionally have concerned themselves with prehistoric contexts, often present Christianity (and other 'world religions') as a final chapter. They often only discuss the 'origins' of these traditions, which suggests that after the 'triumph' of the world religions, the questions of religion become of merely marginal interest to archaeologists and, to a greater extent, the concern of other disciplines (see, e.g., Steadman 2009; less blatantly Insoll 2011). 
The 'controversial evidence' against the cohesion of religion is often called 'folk religion' (e.g. Yoder 1974; Christian 2004). Other terms also used are 'popular' (e.g. Crummey 1993) and 'vernacular' (e.g. Primiano 1995) religion. The most openly problematic term is naturally 'superstition', because of its strong negative connotations (see Cameron 2010: 4-6). I have here chosen to use the term 'folk religion', even though it also has its subtexts (I will return to discuss these further below). Nevertheless, it is the term I am accustomed to since it translates most closely to the Finnish kansanusko (more precisely 'folk belief'), which is the general term for these phenomena in Finnish research (see, e.g., Koski 2011; Enges 2012). I might on some occasions use the term 'folk belief' as a synonym for 'folk religion', but I prefer 'religion' over 'belief' as a broader concept including practices as well as beliefs. The definition of folk religion will be discussed in the next chapter.

I am proposing that the aforementioned believed 'triumph' of uniform Christianity causes (unconscious?) presumptions about religiosity in historical times. As a result, archaeologists who are working with material from historical times have had difficulties interpreting evidence inconsistent with the expectations of past religiosity, as has, for example, been noticed by Roberta Gilchrist (2008: 120). This is why I call the archaeology of folk religion an archaeology of 'strange' behaviour in the title of this paper; a title that may seem slightly provocative, but is meant to be playful and self-critical.

The aim of this paper is to bring forth for archaeologists the complex nature of religiosity in European historical times and to discuss how our understanding of different phenomena can be increased. I will address questions about the nature of folk religion, about who the 'folk' in question are, and what the role of archaeology is in gaining an understanding of the phenomena. I will also offer a brief and limited overview of the current relationship of archaeologists and folk religion in (mainly) northern Europe.

\section{'OFFICIAL' RELIGION AND FOLK RELIGION}

The term 'religion' has been recurrently discussed among scholars. It may even seem like the only commonly shared view on religion is that it is difficult to define (see, e.g., Goody 1961; Asad 1983: 238; 1993: 29, 54; Insoll 2004: 5-23; Whitehouse 2004: 1-3; Steadman 2009: 21-23). When 'folk', another term facing considerable definitional problems (see, e.g., Foster 1953), is added to the equation, this task becomes even more confusing (see, e.g., Yoder 1974; Primiano 1995; Christian 2004). I have elsewhere (Hukantaival in press) discussed a suggestion that the core of the definitional problems of 'religion' and 'ritual' 
lies within the relationship between language and reality, and the difficulties to satisfactorily divide and confine the complexity and dynamic nature of reality. Also, Veikko Anttonen, professor of comparative religion, has pointed out that both 'religion' and 'folk religion' are ultimately nominalist constructs rather than realistic categories (Anttonen 2004; 2012: endnote 3).

This notion does not, however, remove the need for definitions (see also Bell 2007). ${ }^{1}$ For the purpose of this paper, I will leave the discussion of the definition of 'religion' aside, and concentrate on 'folk religion'. The classic way to categorise in scientific approaches has been to form a list of criteria that a member of the category should fulfil (about discussion on this see, e.g., Koski 2011: 110-118). In human sciences, these lists are seldom absolutely strict, and often some flexibility is allowed. Also, a list of possible components belonging to a category can be given, as in the example below.

The following elements can be seen as part of folk religion (Enges 2012: 59-60):

1) Understandings about the genesis of the universe, its structure, and the forces operating within it, understandings of human essence and life-course, death and afterlife, natural and supernatural, society, and its relationship with nature and the universe.

2) Different supernatural agencies, such as gods, spirits, and ancestors.

3) Calendar rites and rites of passage, and corresponding cult places, benign and malignant magic, folk medicine, and its understandings of diseases and healing.

4) Religious specialists, such as cunning folk, witches, and healers.

5) Popular modes of thinking, e.g. understandings of morals, norms, sanctions, and luck.

6) The religious genres of folklore, like memorates, myths, spells, and spiritual songs.

As folklorist Pasi Enges points out, this list is extremely extensive and quite close to the way that many researchers define 'worldview'. It seems that these kinds of definitions easily become too broad in an attempt to include every possible angle of the phenomenon in question. Personally, I prefer a simple definition as the one given by Don Yoder (see below), especially if we keep in mind that definitions are always problematic to some extent and one should not regard them dogmatically (see also Hukantaival in press).

The above list does not offer any means for distinguishing folk religion from 'ethnic' or 'indigenous' religions, such as the religiosity before contact with Christianity. This may cause problems if folk religion is, as a result, perceived only as a relic from pre-Christian times. The relationship with the 'official' 
religion is the element that is relevant to folk religion as discussed here (see also Rydving 2004). This can be seen in Don Yoder's useful definition:

Folk religion is the totality of all those views and practices of religion that exist among the people apart from and alongside the strictly theological and liturgical forms of the official religion. (Yoder 1974: 14)

Historian Euan Cameron, who has studied how European religious authorities have defined and outlined the 'wrong' religiosity, or 'superstition', at different times, calls this the relationship between 'the theory and practice' of religion. He stresses the importance to remember the distinction between the two:

Much writing on the area of superstitions has been bedevilled by a failure to distinguish adequately between what people were instructed to think and do on one hand, and what evidence suggests they thought and did on the other, between norms and reported realities. (Cameron 2010: 6)

On the other hand, folklorist Leonard Norman Primiano, who criticises the terms 'folk/popular' religion and prefers 'vernacular' religion instead, points out that, since vernacular religion is religion as it is lived, it is impossible for the religion of an individual not to be vernacular (Primiano 1995: 44). The critique offered by Primiano is partly directed towards the dichotomy in the terms 'folk' or 'popular' religion against 'official' religion. He suggests that the terms misleadingly imply that somewhere religion exists as a pure element, which is then transformed and contaminated into folk religion (ibid.: 38-40).

The term 'vernacular' is borrowed from linguistics and has meanings such as 'indigenous', 'personal', 'private', 'native', and 'local' attached to it (ibid.: 42-43). Primiano also stresses that even the institutionalised elements of organised religion have a vernacular nature and, in fact, what scholars have referred to as 'official' religion does not exist (ibid.: 45). At this point, Primiano's reasoning raises a question: Why discuss 'vernacular religion' and not just 'religion'? Perhaps Primiano is overstating a bit to make his point clear? In my mind, if we continue taking analogies from linguistics, one could compare the relationship between 'official' religion and folk religion to the relationship between literary language and spoken dialects. One is based on rules agreed upon by a specific group of people while the others are more 'alive', being constantly recreated in use (with a base in tradition, naturally). Still, literary language is also re-discussed, and rules are modified, so it is not static either, just as 'official' religion.

I agree with Primiano about 'official' religion being mostly an ideal type (ibid.: 46), and Cameron's notion of 'theoretical' religion is also somewhat similar (Cameron 2010: 6). Nevertheless, even if 'official' religion only exists in 
theory, it still does exist. As with the above given analogy of literary language and spoken language, the 'official' form and 'folk' form of religion both affect each other. However, the influence of the 'official' religion has perhaps been more prominent because of authority issues. ${ }^{2}$ In addition, as Cameron's study reminds us, the border between (official) religion and 'superstition' has also been constantly negotiated, thus the categories are always dynamic.

Researchers within the cognitive approaches to matters of religion, such as, for example, Harvey Whitehouse and Ilkka Pyysiäinen, point out that there are types of religiosity that are more natural to human cognition (cognitively optimal religion), and types that are more complicated, which need to be learned and rehearsed (cognitively costly religion). Theologically correct religion is cognitively costly while many aspects of folk religion stem from ordinary, everyday thinking, which originates in the immediate experience of individuals. Thus, folk religion aims at practical solutions to everyday issues, not at creating general theories. The 'naturalness' of everyday religiosity leads also persons who are explicitly committed to orthodox concepts to occasionally 'slip' into this mode since it is both easier to handle and more relevant from the everyday point of view than fixed theological systems (Pyysiäinen 2004; Whitehouse 2004: 29-59, 127-134).

The beliefs and practices of religion that have not followed the teachings of the church constitute the folk religion discussed in this paper. Some of these elements could have been inherited from pre-Christian times, but they would still have been reinterpreted from another point of view. Moreover, these elements would be mixed with Christian features, also as interpreted by people. The result is a dynamic, non-consistent whole that includes many elements that could be seemingly contradictory, but still no conflict is experienced in the mind of the practitioner. In the words of folklorist Laura Stark:

[...], folk religion represents neither Christianity's 'contamination' of ethnic folk belief nor the 'misinterpretation' of Christianity by the nonliterate rural populace, but a functional system in which the most useful elements of each belief system are adopted and fashioned into a syncretic whole. (Stark 2002: 30)

As Cameron puts it, the different forms of supernatural power overlapped and intermingled in people's minds (Cameron 2010: 62). This can be illustrated by a folklore example of a building ritual that was recorded in Pihtipudas (in Central Finland) in 1885, and has been published in the Suomen Kansan Muinaisia Taikoja (Ancient Magic of the Finnish People) series (SKMT):

When a stable is rebuilt, a silver coin is split in four pieces and one piece is put in the middle of each first log-joint. Then a guardian-spirit comes 
to the stable. One should say the Lord's Prayer and blessings while doing this. (SKMT IV, 1: I 237\$; translation from Finnish by the author)

As the name of the publication mentioned above (Ancient Magic of the Finnish People) shows, 'magic' is one aspect of folk religion that has attracted much interest. Thus, a quick definition of this term is also in its place before continuing. Magic is also a term with many connotations, and especially classic scholars of religion made a considerable effort to exclude magic from religion (e.g. Frazer 1992 [1922]; Durkheim 1964 [1915]). Magic has been defined in different ways, but I have adopted a view where magic is a means to a certain desired end (see, e.g., Frazer 1992 [1922]: 11-12). Again, the category is dynamic, but the difference with other means to ends is that although the effect is believed to be a result of the action (not necessarily caused by a helping 'supernatural' being), the relationship between cause and effect does not follow the causality of action of a more 'profane' nature (or, as scientifically understood) (see Malinowski 1954 [1948]: 27-33). Thus, for example, placing a horse skull in the foundation of a hearth to prevent cockroaches from breeding in the house is counted as magic ${ }^{3}$ since, according to the everyday reasoning, the connection between cause and effect is not similar to lighting a fire to stay warm. Of course, it must always be kept in mind that the distinction between magical cause and effect and 'mundane' causality has probably not always been as clear-cut to the practitioners as it is to present scholars. ${ }^{4}$

\section{FOLK RELIGION IN SURPRISING (?) PLACES}

As mentioned above, the assumed Christian 'triumphalism' that Mitchell pointed out has affected our expectations regarding evidence of religious phenomena. However, as Robert W. Scribner remarked, another construct of historiography also affects the way that we see 'superstitious' beliefs in Europe's past. In the parts of Europe affected by it, the Reformation has been seen as the 'modernising' and 'civilising' moment in history, which ultimately abolished the popular culture of magic and superstition. Later on this view has been contested, and historians have pointed out that after the Reformation intelligent Protestants continued to believe in demons and spirits, and the Reformation did not remove the threat of witchcraft and hostile sorcery either (Scribner 1993; Cameron 2010: 10-14).

What about the Enlightenment then? As historians Owen Davies and Willem de Blécourt state, it is too crude and misleading to portray the Enlightenment as a period when Europe (finally) cast off the belief in witchcraft and magic. 
The changes that took place were subtle renegotiations rather than huge intellectual and social leaps. What did happen was that intellectual interpretations of aspects of folk magic shifted from being a very real and satanic offence to being a merely fraudulent and morally reprehensive crime. Still, after this decriminalisation of witchcraft, the majority of Europeans still felt the same way about the matters they had before, and the considerable intellectual interest regarding diabolic intervention in human affairs also continued (Davies \& de Blécourt 2004: 1-5). As Cameron put it: "Therefore, it is not in the least surprising if evidence survives of popular 'superstitions' long after the supposed 'decline of magic”' (Cameron 2010: 14).

Davies and de Blécourt also remind us that the Enlightenment has been simplistically portrayed as a period when the beliefs and worldview of the 'elite' and the 'people' irrevocably pulled away from one another (Davies \& de Blécourt 2004: 1). This brings us back to the question of 'folk' in folk religion. Traditionally 'folk' has been connected with rural peasant populations (small, isolated, homogenous, 'primitive') and contrasted with 'urban' cultures, or at least a distinction has been made between 'elite' and lower class 'folk' (see, e.g., Foster 1953; Crummey 1993; Christian 2004). It has been pointed out that both 'folk' and 'popular' carry the same connotation (Crummey 1993: 702; Primiano 1995: 39-40).

The example of the deposited goat skull given at the beginning of this paper was found in the middle of an urban centre, but since it dates to medieval times, the find could be dismissed as belonging to a still 'superstitious' time (before both the Reformation and the Enlightenment). Also, questions about the (truly) urban nature of a medieval town in such a peripheral area as Finland could be put forward. Another example, also from Turku, was found at excavations in 2011 by the residence of Gustaf Gadolin (1769-1843), who was the professor of Hebrew, Greek, and theology at the Academy of Turku (Väisänen 2000). On the bottom of a storage pit, the bones belonging to a hare's left hind leg were found in a position indicating that they had been put there as a hare's foot (see Fig. 2). The storage pit could not be precisely dated, but stratigraphically it belonged to the times just before the Great Fire of 1827, thus coinciding with professor Gadolin's lifetime, or at least the lifetime of his father, professor Jacob Gadolin, who owned the property before him (Pihlman et al. 2012: 3-5). During this time (the late 18th and early 19th centuries), the urban nature of Turku cannot be contested, and again the proximity of the cathedral is striking. The possible connection to the clearly educated 'elite' position of the owner of the property is also interesting. The hare's foot could certainly have belonged to a servant, giving it a more 'proper' lower class connection, but this need not be the case. 


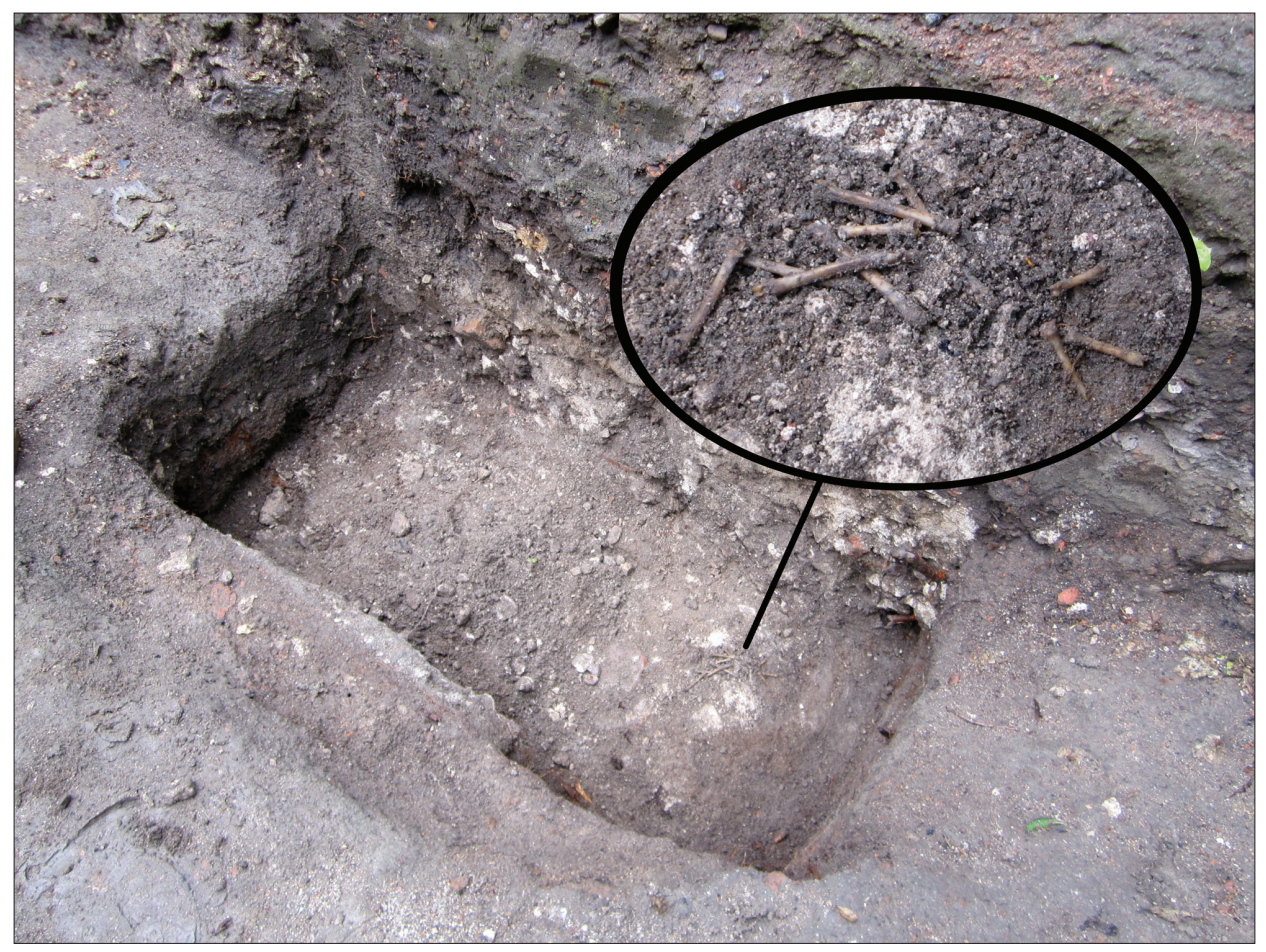

Figure 2. A hare's foot at the bottom of a storage pit on professor Gadolin's premises. Photo by Sonja Hukantaival 2011.

The hare's foot is an ancient magical object, known already c. AD 77-79 by Pliny the Elder. He explains in his Natural History that the hare's foot is known to cure joint pains and gout if the patient carries it as an amulet (Plinius Secundus 1963: 149). The hare's (or rabbit's) foot has since become one of the best known lucky charms and evil-averting objects, but there is little scholarly discussion on the origins and meanings of this custom (see Ellis 2002). In Finnish folklore, the hare's foot is not particularly common when compared to other magical objects. This may point to it being a fairly new (Indo-European?) introduction into the magical repertoire in this area. This could explain why 17 th-century finds of this object are known in the south-western town of Turku (Hukantaival 2007), where new influences were first felt. However, there is some evidence of the use of a hare's foot as a protective magical object in the late 19th century from even such remote areas like Lapland (SKMT IV, 2: XII 41§; SKMT IV, 3: VI $820 \S$, n6), so this matter definitely requires more investigation before anything conclusive can be said. 
The possible connection between the hare's foot and a respected family of professors and clergy may seem puzzling at first glance. It could be pointed out that just two generations before, Gustav Gadolin's grandfather was born a peasant (Väänänen 2000). However, I would still refrain from insisting that magical beliefs can only be connected to lower-class people. For example, the educated elite of the 18th-century Finland still debated whether cattle plague was caused by poisonous air, bad fodder, or witches' projectiles (Nikander 1937). Also, as Laura Stark has discussed, in Early Modern Finland magical practices and beliefs were taught to children as situated knowledge, which means that it was learned by doing in the context of everyday life. For this reason, magic became an unconscious habit: the right way to do things in a certain situation (Stark 2006: 71). In this light, it may be easier to understand that even church men had assimilated certain habits and customs, and did not always question the nature of these (see also Falk 2008: 162). In addition, as discussed above, many aspects of folk religion are cognitively natural, which could also cause persons with theologically correct education to 'slip' in everyday life (Pyysiäinen 2004; Whitehouse 2004: 29-59, 127-134).

Research has shown that evidence of folk religion can be found from all periods, from centre and periphery, in urban and non-urban, as well as lower and upper class contexts (e.g. Valk 2004b: 309; Swann 2005: 116). Also, Primiano points out that the distinction between the clergy and the laity is not absolutely clear since some members of the clergy undoubtedly share many of the beliefs and practices of their lay followers (Primiano 1995: 702). Again, folk religion is to be found where evidence shows that what people thought and did was not the same as they (in theory) were instructed to do (see Cameron 2010: 6), no matter who 'the people' were. Also, folk religion is not confined to 'profane' contexts: as sacred locations, for example, churches and cemeteries are particularly central places for folk beliefs (see, e.g., Koski 2011: 105-108; Falk 2008: 152-163; Valk 2004b: 300).

The believed 'civilised' nature of Europeans (see Cameron 2010: 10-14) has also caused a tendency to see folk religion as something belonging to 'others' (see also Mitchell 2011: 106-107). This has been especially outstanding in the USA, where such archaeological sites where protective charms and divination or conjure items have been found have traditionally been interpreted as occupied by people of African American heritage (Fennell 2000: 281). The same attitude can naturally also be sensed in the idea that folk religion is something belonging to rural, 'simple' people as opposed to civilised, modern, urban people (see above).

The difficulty to understand 'superstitions' among 'civilised' people is still visible in contemporary scientific research, especially outside the humanities. An interest in different 'superstitious' beliefs has risen in the field of psychology 
at the University of Helsinki. The resulting studies are interesting, although they are also quite 'painful' reading for someone with a background in culture studies. The main idea seems to be to try and explain how it is possible that many kinds of 'irrational' beliefs still exist among otherwise 'civilised' people. The attitude towards the object of study (the people who believe) is arrogant in a very '19th-century anthropologist' way (see, e.g., Lindeman \& Aarnio 2006; Aarnio 2007).

Nevertheless, these studies offer some benefits that can be useful for understanding folk religion also for researchers in humanities. As a result of their studies, psychologists have deduced that humans use both an analytical and an intuitive system of reasoning. These systems are independent in a way that makes it possible for an individual to be simultaneously rational and have 'irrational' beliefs, and further:

The finding that paranormal beliefs mainly arise from an intuitive system, instead of a malfunctioning analytical system, explains why the beliefs do not vanish with the increase of education, scientific knowledge, and rational thinking. (Aarnio 2007: 6)

Psychologists' studies did indicate that individuals with a higher education are more sceptical than individuals with a lower education (e.g. Aarnio 2007: 6), but this view is challenged in another analysis of contemporary beliefs, made from the viewpoint of a folklorist (Hänninen 2009: 51-52).

Since psychologists are puzzled by 'superstitions' today, it surely should not be surprising to find evidence of folk religion at any time in the past. I also hope to have shown that evidence of folk religion should not be surprising in any context: rural or urban, domestic or ecclesiastic, educated or illiterate, upper or lower class and no matter what ethnicity is in question. There have certainly been differences both between individuals and between times and places, but the nature of these differences can better be discussed after some more research without obvious preconceptions has been carried out, hopefully with valuable contributions from archaeologists, in addition to other disciplines.

\section{THE MULTIDISCIPLINARY ARCHAEOLOGY OF FOLK RELIGION}

How can we then reach the 'practice of religion', as Cameron expressed it? In Finland, research on folk religion has traditionally been the interest of the disciplines of folkloristics and comparative religion. As a result, the material culture of folk religion has largely been excluded from study, thus serving only 
as illustrative material if considered at all (see, e.g., Issakainen 2006: 1-2). At the moment, there seem to be a rising interest among scholars of different disciplines in matters of folk religion in Europe. As Mitchell remarks, a positive development is currently taking place in the research:

Finally, after years of working in relatively atomistic parallel universes, such necessarily interrelated fields as folklore, history, philology, and archaeology are once again recognizing the advantages of a comprehensive approach to such subjects as witchcraft, magic, and religion, [...]. (Mitchell 2011: 22)

In an ideal situation, a truly multidisciplinary research would be realised through a joint project, comprising professionals from different disciplines all treating the phenomenon in question from their own viewpoints and discussing different ways of approaching the material. However, in practice it is often up to the individual researcher to try to operate with the different sources available. This calls for carefulness and good knowledge of source-criticism involved in each type of source. As always, special caution should be employed in combining evidence if different sources are temporally and/or regionally distant from each other (see, e.g., Gazin-Schwartz \& Holtorf 1999: 13).

In addition to archaeological finds, other sources that can be used for understanding folk religion are, for example, historical sources, such as witchcrafttrial records, legal texts, and 'superstition treatises' (see, e.g., Mitchell 2011; Cameron 2010), as well as folklore material; for example, accounts on magical practices, and ethnological sources (mainly the material culture of folk religion not collected archaeologically). This list is by no means exclusive, and the possibilities vary in different countries with distinct research traditions and a different emphasis on the sources available.

Since extensive folklore collections exist in Finland, and I am using these sources in my own research on building magic, I chose to discuss some sourcecritical aspects of this material as an example (see also Gazin-Schwartz \& Holtorf 1999; Valk 2006). ${ }^{5}$ Most of the folklore accounts concerning Finnish folk religion have been recorded in the late 19 th and early 20 th centuries - a point that is important to bear in mind when working with this material. Other vital aspects of understanding are concerned with how the material has come to be as it is - the 'formation processes' of folklore material, to use a term familiar to archaeologists (see Schiffer 1987).

Recently, these questions have been discussed, for example, by folklorist Kaarina Koski. She reminds us that at the time that most of the material was collected, the so-called 'Finnish research method' was prevailing in folkloristics, and it exerted significant influence on how the material was formed. According 
to the mentality of the period, folklore accounts were understood as a collective 'voice of the past', and individual accounts were detached from their context. On the other hand, the benefit of the research paradigm was that it needed large collections to achieve its objective to find the believed 'original forms' of the traditions. The influence of the individual collectors on the material was also considerable and researchers of the period controlled the 'authenticity' and 'folksiness' of the accounts. Collectors were not interested in asking about traditions in central areas since these were not thought to be places where the 'original' elements had survived (Koski 2011: 28-39; see also Anttonen 2004: 74-75). For these reasons, it is also crucial to familiarise oneself with the collector's guides (e.g. Mustonen 1936 [1885]) of the period for a better understanding of the formation of the folklore material.

As we are aware of the source-critical issues involved, knowledge of folklore material helps our understanding of matters of folk religion and more broadly the 'mentality of the past' (see Valk 2006: 316; also Stark 2006). Since all these different potential source materials are at hand, one could ask what the role of archaeology is in the research of folk religion. The neglected material culture of folk religion has already been mentioned, but also one critical point about many of these other sources has been remarked by historian Cameron as follows: "Nothing intrinsic to the pastoral superstition-treatises proves that any identifiable group of people actually practiced the activities that it condemns" (Cameron 2010: 69-70). ${ }^{6}$ To discuss whether the practices were actually real and not just imagined, Cameron turns to their survived physical evidence (Cameron 2010: 69-72). Who else than archaeologists are most competent to discuss the physical evidence of past actions?

As a result of the different 'formation processes' of varied source materials, only parts of the 'practice of religion' have been recorded and have survived. One example is given by Ralph Merrifield, who could be called one of the pioneers in discussing matters of folk religion from an archaeological perspective. When ruminating over the numerous finds of deliberately concealed shoes in the constructs of buildings, he points out that no surviving folklore or other accounts exist about this practice, even though the physical evidence shows that it has been a common custom (Merrifield 1987: 133-134; see also Swann 20057). A similar example can also be given from Finland. It seems from the archaeological material that whetstones (both used and unused) have often been concealed in buildings (Hukantaival 2007: 68; 2011: 49). However, in over 700 folklore accounts on concealing objects in buildings thus far examined by the author, no whetstones are mentioned (although they are mentioned, for example, in hunting-magic, see SKMT I 306\$). Concealed whetstones in buildings have also been found in southern Scandinavia (Falk 2008: 115). The whetstone "on which 
iron tools have been often sharpened" is also one of the magical objects known to Pliny the Elder in his Natural History from circa AD 77 (Plinius Secundus 1963: 35; see also Mitchell 1985 on whetstone symbolism).

Archaeologists can also contribute to the research of folk religion by observing different phenomena in a long-term perspective. For example, Swedish archaeologist Ann-Britt Falk has studied changes in elements of folk religion (building concealments) through changes in the archaeological material, building on the idea that the latter refer to changed meanings (Falk 2008: 59). According to her studies, the Reformation had a bigger effect on folk religion than conversion to Christianity, which is quite an interesting observance (ibid.: 74, 184-201).

As Cameron remarked, there is a difference between how people were instructed to think and behave and what evidence suggests that they actually did. Archaeological finds tell us about what people actually did, in a highly reliable way, compared to many other sources that are often heavily influenced by authorities. To access what they thought, other sources may be more informative. In any case, there is no sense in confining the study of folk religion to only one type of source material, while a much broader understanding can be achieved from multiple sources.

\section{ARCHAEOLOGISTS AND FOLK RELIGION}

Even though the 'archaeology of folk religion' is a marginal offshoot of the also quite marginal 'archaeology of religion' (see, e.g., Insoll 2004: 1-5), it is still not a complete novelty. In this chapter, I will not attempt a comprehensive view on the subject, but rather make a short survey of some of the themes connected to folk religion, which have been discussed by archaeologists. Because of my own northern location, this survey is biased towards studies made in the northern parts of Europe.

One of the first serious attempts to define an archaeological field of research connected with folk religion is the aforementioned Ralph Merrifield's book The Archaeology of Ritual and Magic (1987). The intention of the book was to guide archaeologists to pay attention to evidence of religion in any period, but its unprejudiced attitude towards matters of folk religion in historical times might have had a most noticeable impact. The most obvious follower of Merrifield is Brian Hoggard with his 'archaeology of counter-witchcraft' (Hoggard 2004). Matters of folk religion in connection to death and burial have also interested British archaeologists. Roberta Gilchrist's awarded article on evidence of magic in medieval burials is a relevant discussion on the matter (Gilchrist 2008), and recently Sarah Tarlow (2011) has discussed attitudes towards death and the 
dead in Early Modern Britain and Ireland from multiple angles, including the viewpoint of folk belief.

In Scandinavia, an archaeological plea for noticing the unused potential of research in folk religion was made by Norwegian Volker Demuth in a presentation at Kontaktseminaret in 1999. As an example, he discussed how matters of folk religion can be reached through the decorations on Early Modern ceramics (Demuth 2000). In Finland, Marianna Niukkanen has touched upon the same subject of magical meanings in the ceramics decorations (Niukkanen 2007). Both Demuth and Niukkanen refer to the Dutch researcher Maria GarthoffZwaan, who discussed the symbolic meanings (fertility, regeneration and protection against evil) of the decorations already in 1988 (Niukkanen 2007: 34 > Garthoff-Zwaan \& Ruempol 1988).

Since my own research subject is ritual concealments made in buildings (Hukantaival 2007; 2009; 2011), I focus on this topic specifically. The phenomenon of deliberately concealed objects in buildings has attracted the interest of many archaeologists studying historical times, perhaps since similar phenomena had first been discussed in prehistoric contexts (e.g. Capelle 1987; Henriksen 1998). The most extensive work made in northern Europe on building concealments in historical times is the licentiate thesis by Swede Ann-Britt Falk, already mentioned above (Falk 2008). Articles about the topic have also been written, for example, in the Czech Republic, Hungary and Poland (Vařeka 1994; Daróczi-Szabó 2010; Baron 2012), to mention but some studies outside the Nordic countries.

As well as it seems to be in other parts of Europe (see, e.g., Mitchell 2011: 22 ), the amount of recent publications indicates a rising interest in the matters of folk religion in Finland, after some more silent times. This can be seen as a growing amount of publications grazing the topic also among archaeologists. Juha Ruohonen is conducting research on cemeteries on islands, which in itself can be seen as part of folk religion since they differ from 'official' instructions on burial (see, e.g., Ruohonen 2010), but he has also written an article about evidence of a magic practice involving a coin wrapped in red woollen thread in one of these island cemeteries (Ruohonen 2011). Also, Timo Muhonen's research topic is related to matters of folk religion. He studies stone cairns connected with offerings and other practices and beliefs besides the better known connection to prehistoric burials (e.g. Muhonen 2010; 2011). Some interest in folk religion has also been visible in the studies concerning contexts in northern Finland and Lapland (e.g. Herva \& Ylimaunu 2009; Äikäs \& Guttorm 2011).

In Estonia, especially Heiki Valk has repeatedly discussed matters connected to folk religion. He has, for example, discussed evidence of folk religion in burial customs, like beliefs connected to village cemeteries (Valk 1995), and 
urban furnished graves, from the point of view of regional and ethnosocial differences (Valk 2004a). Additionally, he has studied the relationship between Christian holy sites and different sacred places of folk religion, noticing that Christianity has influenced these places in various ways (Valk 2004b; 2008). To mention another recent Estonian archaeological study connected to folk religion, an article has been written discussing a find of a stone disk engraved with symbols (most likely some sort of talisman), a unique find in Estonia (Jonuks et al. 2010). Also, the phenomenon of re-using Stone Age tools as magical 'thunderbolts' has recently been discussed in Estonia (Johanson 2009). These 'thunderbolts' have attracted the attention of archaeologists also elsewhere in Europe (e.g. Carelli 1996; Muhonen 2006).

In addition to more traditional topics of research on folk religion (such as preChristian survivals, offerings and magic), some interest has also risen towards the dynamic 'border area' between 'official' and folk religion. Private devotion (see, e.g., Webb 2005) is one example of such a 'border area', certainly involving many elements approved and encouraged by the 'official' religious authorities, but at the same time a 'dangerous' zone with a profound possibility for folk interpretations of religion (see Cameron 2010: 50-62). Also, for example, Christian magic is a subject that has certainly been avoided as an unorthodox topic for discussion, but this, too, is now being explored by daring researchers (e.g. Cameron 2010: 58-62; Mitchell 2011: 43-73). Janne Harjula gave a presentation at the Annual Meeting of the European Association of Archaeologists in 2012 , discussing some finds of medieval wooden vessels with parts of prayers carved on them as rune inscriptions (Harjula 2012). The fluctuating border between private devotion and magic is an interesting question to be discussed in this connection as well.

One thing that can be noticed in many of these studies mentioned above is that there is little consensus among archaeologists about what folk religion is. Every researcher certainly defines the terms he/she uses according to his/ her own research tradition, but the source of the confusion might in this case be that, in general, research discussing folk religion is not well known among archaeologists. It seems that the idea that folk religion is pre-Christian religion surviving in defiance to Christianity or as a relic in peripheral areas is quite common (see, e.g., Daróczi-Szabó 2010; Valk 2004b). This is the traditional view that has influenced much of the discussion and the formation of folklore records as mentioned above. Perhaps the other extreme is the 'relational ontology' preferred by Herva \& Ylimaunu (2009), in which matters of folk religion are tried to be explained outside religion altogether.

The 'archaeology of folk religion' is not a uniform field, and perhaps few of the researchers in question even consider themselves to be part of such a genre. 
I do not see this as a problem in itself, but discussing the theories and methods in use, and the needs for developing them, is easier after a field of research has been defined. Most of the research on folk religion carried out by archaeologists has concentrated on single find groups without wider connections to other aspects of folk religion, which is understandable since the phenomenon of folk religion is overwhelmingly vast and one could say that the 'archaeology of folk religion' is still in a basic research phase. However, it is also refreshing to notice that matters of religion are being integrated more widely into archaeological research of historical times, as in Roberta Gilchrist's recent book on medieval life in general (Gilchrist 2012).

\section{CONCLUSIONS}

Folk religion as defined in this paper is religion interpreted and re-interpreted by people in their everyday life. Different traditions have certainly had their part in this interpretation, but folk religion is still not static, and I would like to stress that folk religion is more than only survivals and persistence of preChristian religion. The relationship between 'official' religion and folk religion is a complex matter that will hopefully be discussed more deeply in the future.

Archaeologists have much to add to the research of folk religion since the real 'practice of religion' is to be reached most reliably through the material remains of actual customs. Nevertheless, without other sources these material remains have less potential than if they were combined with them. Since folk religion as defined in this setting is a historical phenomenon, the utilisation of historical and folkloristic sources is less problematic than in case they are used together with prehistoric finds. Still, a good knowledge of source-critical issues is needed.

If archaeological research is combined with the research on folk religion more comprehensively, it may become possible to trace the traditions (the ones that are manifested materially) and their changes back in time. This kind of research could help us answer questions about how elements of religion are preserved and how they change, and this could potentially also contribute to the study of prehistoric religions, for which additional sources are not available. There have been speculations and assumptions about the survival of religious elements, but a comprehensive study on the subject is still lacking. In this connection, a crucial question is if evidence of static customs can be considered as evidence of static beliefs, in the same way as changing customs have been interpreted as evidence of changing beliefs (see, e.g., Falk 2008). The connection between practice and belief should also be discussed more widely to answer this question. 
Even though I strongly support the use of additional sources when interpreting archaeological remains connected to folk religion, I do see the 'archaeology of folk religion' as a part of the 'archaeology of religion', not as a separate field. It has been suggested within the field of comparative religion that the concept of folk religion has served its purpose by pointing out that religion is more than theological, only textual, elitist, etc., and could thus already be discarded (Rydving 2004: 149). I do see the point in this: folk religion is included in religion, but I still feel that folk religion as a concept has not yet 'done its duty' in the field of archaeology. The discussion that has been conducted within comparative religion is not so well known outside it, so a 'set of training wheels' is in its place for the time being.

It is also good to remember that folk religion is not only to be found in the past. When looking around today, with the role of 'official' religion partly replaced by a scientific worldview, there are numerous different 'folk interpretations' about matters of religion and other beliefs (for example, about health and diet), as has been noticed by the psychologists mentioned above (Lindeman \& Aarnio 2006; Aarnio 2007). Magical thinking has not disappeared either, as the example below (Fig. 3) of modern folk religion circulating in the social media on the Internet in the year 2012 shows.

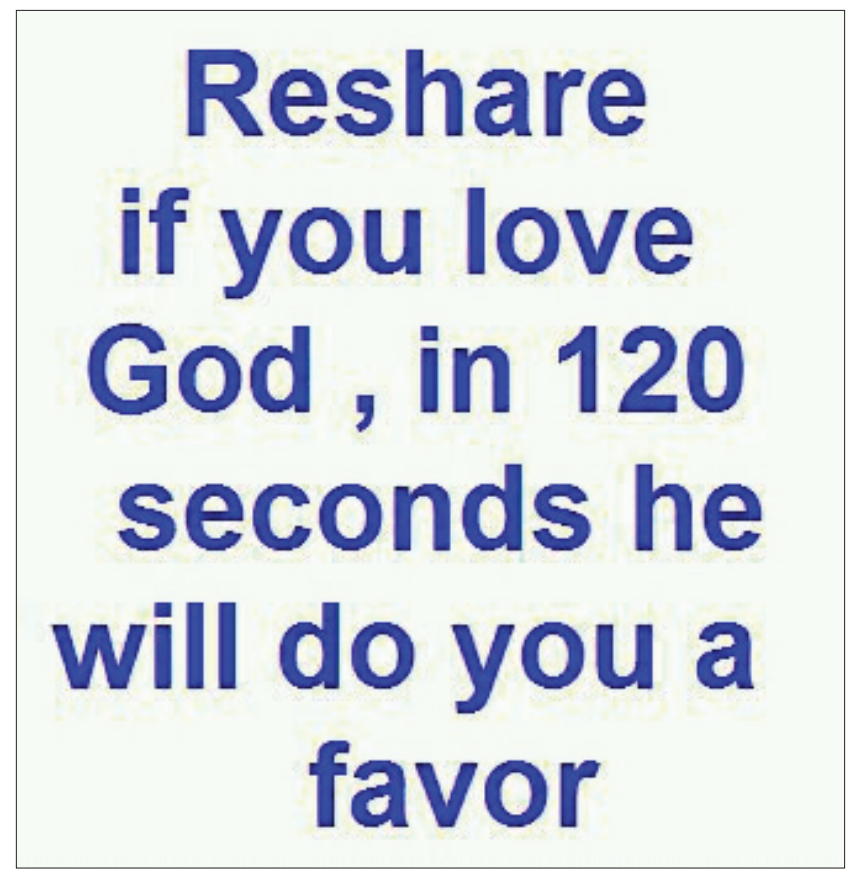

Figure 3. Modern folk religion as spread in the social media (Facebook) on the Internet. 


\section{ACKNOWLEDGEMENTS}

The author wishes to thank the Turku Centre for Medieval and Early Modern Studies (TUCEMEMS) for financial support to attend the Nordic TAG-conference in Oulu (2012) resulting in this paper, as well as Timo Muhonen for fruitful discussions on the topic of this paper, and professor Veikko Anttonen for valuable comments on the manuscript.

\section{NOTES}

1 In my opinion it is more fruitful to accept categories without strict borders, and give a definition according to this (see Hukantaival forthcoming), than leave the difficult task undone altogether, as has also been done recently (Issakainen 2012: 21-22).

2 See also, e.g., Mitchell 2011: 39-40 about the influences of 'paganism' on Christianity.

3 There are around fifty examples of this custom known to the author, mostly in the collections of the Folklore Archives of the Finnish Literature Society in Helsinki (SKS KRA) (e.g. SKS KRA Oulu A. Leino b) 608. 1892).

4 Although Malinowski did observe that the distinction was very clear indeed in the society he studied in Melanesia (Malinowski 1954: 27-33).

5 This part has been influenced by fruitful discussions with Timo Muhonen. I am grateful, but also accept all responsibility for the current outcome.

6 The same limitation to the folklore material on magic has been noticed by Tenka Issakainen. There is no way to be sure if the magic described has actually been practiced or if folklore describes the ways that certain circumstances have been explained. Thus she is not discussing magic as rites (Issakainen 2012: 12).

7 June Swann started researching these finds already in 1958 (Swann 2005: 115).

\section{ARCHIVAL SOURCES}

SKS KRA - Suomalaisen Kirjallisuuden Seuran Kansanrunousarkisto (The Folklore Archives of the Finnish Literature Society)

\section{REFERENCES}

Aarnio, Kia 2007. Paranormal, Superstitious, Magical, and Religious Beliefs. Department of Psychology, Studies 44. Helsinki: University of Helsinki. Available at http://urn.fi/URN:ISBN:978-952-10-4202-7, last accessed on September 19, 2013. 
Äikäs, Tiina \& Guttorm, Anni 2011. Kristinuskon ja etnisen uskon kohtaamisia pohjoisessa. [Encounterings between Christianity and Ethnic Religion in the North.] In: J. Ikäheimo \& R. Nurmi \& R. Satokangas (eds.) Harmaata näkyvissä. Kirsti Paavolan juhlakirja. Vaasa: Waasa Graphics, pp. 83-94.

Anttonen, Veikko 2004. Theory and Method in the Study of 'Folk Religion'. Temenos: Nordic Journal of Comparative Religion, Vols. 39-40, pp. 73-79.

Anttonen, Veikko 2012. Literary Representation of Oral Religion. Organizing Principles in Mikael Agricola's List of Mythological Agents in Late Medieval Finland. In: Catharina Raudvere \& Jens Peter Schjødt (eds.) More than Mythology. Narratives, Ritual Practices and Regional Distribution in Pre-Christian Scandinavian Religions. Lund: Nordic Academic Press, pp. 185-223.

Asad, Talal 1983. Anthropological Conceptions of Religion: Reflections on Geertz. Man: New Series, Vol. 18, No. 2, pp. 237-259, http://dx.doi.org/10.2307/2801433.

Asad, Talal 1993. The Construction of Religion as an Anthropological Category. In: Talal Asad (ed.) Genealogies of Religion: Discipline and Reasons of Power in Christianity and Islam. Baltimore \& London: Johns Hopkins University Press, pp. 27-54.

Baron, Justyna 2012. Ritual and Cultural Change. Transformations in Rituals at the Junction of Pagan Religion and Christianity in Early Medieval Poland. In: B. Gediga \& A. Grossman \& W. Piotrowski (eds.) Rytm Przemian Kulturowych $w$ Pradziejach $i$ Średniowieczu. Biskupin-Wrocław, pp. 449-464.

Bell, Catherine 2007. Response: Defining the Need for a Definition. In: Evangelos Kyriakidis (ed.) The Archaeology of Ritual. Cotsen Advanced Seminars 3. Los Angeles: Cotsen Institute of Archaeology, pp. 277-288.

Cameron, Euan 2010. Enchanted Europe. Superstition, Reason \& Religion 1250-1750. Oxford: Oxford University Press.

Capelle, Torsten 1987. Eisenzeitliche Bauopfer. Frühmittelalterliche Studien. Jahrbuch des Instituts für Frühmittelalterforschung der Universität Münster, Vol. 21, pp. 182-205.

Carelli, Peter 1996. Blixtar och dunder, magiska under. Om åskstenstraditionen och förekomsten av stenåldersfynd i medeltida kulturlager. [Lightning and Thunder, Magic Miracles. About the Thunderstone Tradition and the Finds of Stone Age Objects in Medieval Cultural Layers.] Fornvännen: Journal of Swedish Antiquarian Research, Vol. 91, pp. 153-170. Available at http://samla.raa.se/ xmlui/bitstream/handle/raa/2840/1996_153.pdf?sequence=1, last accessed on November 27, 2013.

Christian, William A. 2004. Folk Religion: An Overview. In: Lindsay Jones (ed.) Encyclopedia of Religion. Second edition, Vol. 1. Detroit: Macmillan Reference USA.

Crummey, Robert O. 1993. Old Belief as Popular Religion: New Approaches. Slavic Review, Vol. 52, No. 4, pp. 700-712, http://dx.doi.org/10.2307/2499648.

Daróczi-Szabó, Márta 2010. Pets in Pots: Superstitious Belief in a Medieval Christian (12th-14th c.) Village in Hungary. In: D. Campana \& P. Crabtree \& S.D. deFrance \& J. Lev-Tov \& A. Choyke (eds.) Anthropological Approaches to Zooarchaeology. Colonialism, Complexity, and Animal Transformations. Oxford: Oxbow Books, pp. 244-249.

Davies, Owen \& de Blécourt, Willem 2004. Introduction: Beyond the Witch Trials. In: Owen Davies \& Willem de Blécourt (eds.) Beyond the Witch Trials: Witchcraft 
and Magic in Enlightenment Europe. Manchester: Manchester University Press, pp. 1-8.

Demuth, Volker 2000. Spor av folkelig religion i arkeologisk materiale fra etterreformatorisk tid. Keramikk som kulturhistorisk kilde. [Traces of Folk Religion in Archaeological Material from Post-Reformation Times. Ceramics as a Cultural Historic Source.] V. Berge \& L. Nordeide \& T.B. Olsen \& K. Solevåg (eds.) Kontaktstensil 42. Religion og Ritual. Bergen: Fellesnordisk Råd for Arkeologistuderende, pp. 77-84.

Durkheim, Émile 1964 [1915]. The Elementary Forms of the Religious Life. Transl. by Joseph Ward Swain. Fifth edition. London: George Allen \& Unwin Ltd.

Ellis, Bill 2002. Why Is a Lucky Rabbit's Foot Lucky? Body Parts as Fetishes. Journal of Folklore Research, Vol. 39, No. 1, pp. 51-84. Available at http://www.jstor. org/discover/10.2307/3814831?uid=3737920\&uid=2134\&uid=2\&uid=70\&uid=4 \&sid=21103065226413, last accessed on November 27, 2013.

Enges, Pasi 2012. "Minä melkein uskon". Yliluonnollinen ja sen kohtaaminen tenonsaamelaisessa uskomusperinteessä. ["I Almost Believe." Encounters with the Supernatural in Teno Sàmi Belief Tradition.] Turku: Annales Universitatis Turkuensis C 338. Available at http://urn.fi/URN:ISBN:978-951-29-5003-4, last accessed on September 23, 2013.

Falk, Ann-Britt 2008. En grundläggande handling. Byggnadsoffer och dagligt liv i medeltid. [A Fundamental Action. Building Offerings and Everyday Life in Medieval Times.] Vägar till Midgård 12. Lund: Nordic Academic Press.

Fennell, Christopher C. 2000. Conjuring Boundaries: Inferring Past Identities from Religious Artifacts. International Journal of Historical Archaeology, Vol. 4, No. 4, pp. 281-313, http://dx.doi.org/10.1023/A:1009534401909.

Foster, George M. 1953. What is Folk Culture? American Anthropologist, Vol. 55, No. 2, pp. 159-173, doi: 10.1525/aa.1953.55.2.02a00020.

Frazer, James George 1992 [1922]. The Golden Bough. A Study in Magic and Religion. Abridged edition. The 1992 reprint. London: Papermac.

Garthoff-Zwaan, Maria \& Ruempol, Alma P.E. 1988. Communicerende vaten. Beeldtaal van slibversiering op laat-middelleeuws aardwerk in de Nederlanden. [Communicating Vessels. Imagery of Slip Decoration on Late Medieval Pottery in the Netherlands.] Rotterdam: Museum Boymans-Van Beuningen.

Gazin-Schwartz, Amy \& Holtorf, Cornelius 1999. 'As long as ever I've known it...' On Folklore and Archaeology. In: Amy Gazin-Schwartz \& Cornelius J. Holtorf (eds.) Archaeology and Folklore. Theoretical Archaeology Group (TAG)-series. London \& New York: Routledge, pp. 3-25.

Gilchrist, Roberta 2008. Magic for the Dead? The Archaeology of Magic in Later Medieval Burials. Medieval Archaeology, Vol. 52, No. 1, pp. 119-158, http://dx.doi. org/10.1179/174581708x335468.

Gilchrist, Roberta 2012. Medieval Life. Archaeology and the Life Course. Woodbridge: Boydell Press.

Goody, Jack 1961. Religion and Ritual: The Definitional Problem. The British Journal of Sociology, Vol. 12, No. 2, pp. 142-164, http://dx.doi.org/10.2307/586928.

Hänninen, Kirsi 2009. The Construction of Self in Finnish First-Person Supernatural Encounter Narratives. Doctoral thesis at the Ohio State University. Available 
at https://etd.ohiolink.edu/ap:0:0:APPLICATION_PROCESS=DOWNLOAD_ ETD_SUB_DOC_ACCNUM:::F1501_ID:osu1261592657,inline, last accessed on September 23, 2013.

Harjula, Janne 2012. Runic Inscriptions on 14th-15th Century Wooden Stave Vessels in Turku - Expressions of Language, Education and Domestic Religion. In: E.-M. Viitanen (ed.) 18th Annual Meeting of the European Association of Archaeologists, 29 August - 1 September 2012 Helsinki, Finland. Abstracts. EAA Book of Abstracts, pp. 126-127.

Henriksen, Mogens Bo 1998. Guden under gulvet - ofringer under fynske huse fra ældre jernalder. [The God under the Floor - Offerings under Buildings in Funen from the Early Iron Age.] Fynske minder, pp. 191-212.

Herva, Vesa-Pekka \& Ylimaunu, Timo 2009. Folk Beliefs, Special Deposits, and Engagement with the Environment in Early Modern Northern Finland. Journal of Anthropological Archaeology, Vol. 28, No. 2, pp. 234-243, http://dx.doi. org/10.1016/j.jaa.2009.02.001.

Hoggard, Brian 2004. The Archaeology of Counter-Witchcraft and Popular Magic. In: O. Davies \& W. de Blécourt (eds.) Beyond the Witch Trials: Witchcraft and Magic in Enlightenment Europe. Manchester: Manchester University Press, pp. 167-186.

Hukantaival, Sonja 2007. Hare's Feet under a Hearth - Discussing 'Ritual' Deposits in Buildings. In: V. Immonen \& M. Lempiäinen \& U. Rosendahl (eds.) Hortus novus. Fresh Approaches to Medieval Archaeology in Finland. Archaeologia Medii Aevi Finlandiae XIV. Turku: SKAS, pp. 66-75. Available at http://www. academia.edu/687532/Hares_feet_under_a_hearth_-_Discussing_ritual_deposits_ in_buildings, last accessed on November 27, 2013.

Hukantaival, Sonja 2009. Horse Skulls and 'Alder-Horse': The Horse as a Depositional Sacrifice in Buildings. In: A. Bliujienè (ed.) The Horse and Man in European Antiquity (Worldview, Burial Rites, and Military and Everyday Life). Archaeologia Baltica, Vol. 11, pp. 350-356.

Hukantaival, Sonja 2011. "En hästskalle i murgrunden”. Arkeologiska och folkloristiska exempel på byggnadsoffer i Finland under historisk tid. [A Horse Skull in the Foundation. Archaeological and Folkloristic Examples of Building Deposits in Finland in Historic Times.] Fornvännen: Journal of Swedish Antiquarian Research, Vol. 106, pp. 43-53. Available at http://samla.raa.se/xmlui/bitstream/ handle/raa/3260/2011_043.pdf?sequence=1, last accessed on September 23, 2013.

Hukantaival, Sonja in press. Understanding Past Actions: Changing Attitudes towards Ritual, Religion, and Everyday Life. Submitted for publication in the BASE 5 seminar publication.

Insoll, Timothy 2004. Archaeology, Ritual, Religion. London: Routledge.

Insoll, Timothy (ed.) 2011. The Oxford Handbook of the Archaeology of Ritual \& Religion. Oxford: Oxford University Press.

Issakainen, Touko [Tenka] 2006. "Vainajien lapset". Taikaesineet ajassa. [“The Children of the Deceased". Magic Objects in Time.] Ennen ja nyt, Vol. 2. Available at http:// www.ennenjanyt.net/2006_2/issakainen.pdf, last accessed on September 23, 2013.

Issakainen, Tenka 2012. Tavallista taikuutta. Tulkinta suomalaisten taikojen merkityksistä Mikko Koljosen osaamisen valossa. [Ordinary Magic. An Interpretation 
of the Meanings of Finnish Magic Practices in the Light of Mikko Koljonen's Expertise.] Annales Universitatis Turkuensis, C 347. Turku: TYJ. Available at http://urn.fi/URN:ISBN:978-951-29-5158-1, last accessed on September 23, 2013.

Johanson, Kristiina 2009. The Changing Meaning of 'Thunderbolts'. Folklore: Electronic Journal of Folklore, Vol. 42, pp. 129-174. Available at http://www.folklore.ee/ folklore/vol42/johanson.pdf, last accessed on September 23, 2013.

Jonuks, Tõnno \& Friedenthal, Meelis \& Haak, Arvi 2010. Värtnakeder, talisman või nõiaese - märkidega kiviketas Viljandimaalt Rattama talust. [A Spindle Whorl, a Talisman or a Witchcraft Object: A Stone Disc Marked with Symbols from Rattama Farm in Viljandimaa.] In: Ü. Tamla (ed.) Ilusad asjad. Tähelepanuväärseid leide Eesti arheoloogiakogudest. [Beautiful Things: Significant Artefacts from the Archaeological Collections in Estonia.] Muinasaja teadus, Vol. 21. Tallinn: Tallinna Ülikooli Ajaloo Instituut, pp. 269-286.

Koski, Kaarina 2011. Kuoleman voimat. Kirkonväki suomalaisessa uskomusperinteessä. [Powers of Death. Church-väki in Finnish Folk Belief Tradition.] Suomalaisen Kirjallisuuden Seuran Toimituksia 1313. Helsinki: SKS.

Lindeman, Marjaana \& Aarnio, Kia 2006. Superstitious, Magical, and Paranormal Beliefs: An Integrative Model. Journal of Research in Personality, Vol. 41, No. 4, pp. 731-744, http://dx.doi.org/10.1016/j.jrp.2006.06.009.

Malinowski, Bronisław 1954 [1948]. Magic, Science and Religion and Other Essays. The 1954 reprint. New York: Anchor Books A23.

Merrifield, Ralph 1987. The Archaeology of Ritual and Magic. New York: New Amsterdam Books.

Mitchell, Stephen A. 1985. The Whetstone as Symbol of Authority in Old English and Old Norse. Scandinavian Studies, Vol. 57, No. 1, pp. 1-31.

Mitchell, Stephen A. 2011. Witchcraft and Magic in the Nordic Middle Ages. Philadelphia: University of Pennsylvania Press.

Muhonen, Timo 2006. Kolme ajallista näkökulmaa ukonvaajoihin. Kivikauden kiviesineet myöhempien aikojen kuriositeetteina. [Three Temporal Views on Thunderbolts. Stone Age Stone Objects as Curiosities of Later Times.] Kuriositeettikabi.net 3, pp. 1-23. Available at http://kuriositeettikabi.net/numero3/Ukonvaajat.pdf, last accessed on September 23, 2013.

Muhonen, Timo 2010. Kiviröykkiöt parannusperinteen näkökulmasta. [Stone Cairns from the Viewpoint of Healing Tradition.] In: S. Knuuttila \& U. Piela \& L. Tarkka (eds.) Kalevalamittaisen runon tulkintoja. Kalevalaseuran vuosikirja 89. Helsinki: SKS, pp. 200-223.

Muhonen, Timo 2011. Chasing the Ghost: Empty Cairns of the Finnish Lake District with Glances of Folk Tradition. In: J. Harjula \& M. Helamaa \& J. Haarala (eds.) Times, Things \& Places. 36 Essays for Jussi-Pekka Taavitsainen. Turku: J.P. Taavitsainen Festschrift Committee, pp. 320-343.

Mustonen O.A.F. 1936. Taikanuotta: eli opas taikojen kerääjille. [The Magic Seine: A Guide for Collectors of Magic.] Fifth edition. Helsinki: SKS.

Nikander, Gabriel 1937. Boskapspesten i Österbotten på 1700-talet. [The Rinderpest in Ostrobothnia during the 18th Century.] Budkavlen, No. 1, Meddelanden från institutet för nordisk etnologi vid Åbo Akademi, pp. 1-13. 
Niukkanen, Marianna 2007. The Form and Decoration of Redware Vessels: Functionality and Hidden Symbolic Meanings. In: K. Majantie (ed.) Ruukkuja ja ruhtinaita : saviastioita ja unikaakeleita ajalta 1400-1700 = Pots and princes : ceramic vessels and stove tiles from 1400-1700 = Fat och furstar : lerkärl och ungskakel från 1400-1700. Archaeologia Medii Aevi Finlandiae XII. Turku: SKAS, pp. 26-35.

Pihlman, Aki \& Hukantaival, Sonja \& Lompolo, Virva \& Martiskainen, Heidi \& Saloranta, Elina 2012. Turku I. Tuomiokirkonpuisto. Kaupunkiarkeologinen kaivaus 2011. Kaivausraportti, Turun museokeskus. [Turku I. Cathedral Park. A Town Archaeological Excavation 2011.] Unpublished excavation report. The Museum Centre of Turku.

Plinius Secundus, Caius 1963. Natural History. Vol. 8, Libri XXVIII-XXXII. Translated by W.H.S. Jones. The Loeb Classical Library 418. Cambridge: Harvard University Press.

Primiano, Leonard Norman 1995. Vernacular Religion and the Search for Method in Religious Folklife. Western Folklore, Vol. 54, No. 1, pp. 37-56, http://dx.doi. org/10.2307/1499910.

Pyysiäinen, Ilkka 2004. Folk Religion and Theological Correctness. Temenos, Vols. 39-40, pp. 151-165.

Ruohonen, Juha 2010. Kuolleiden saaret. Historiallisen ajan keskisuomalaisten saarihautausmaiden luonne ja käyttö hautapaikkoina. [Islands of the Dead. The Nature and Use of Central Finnish Historical Island Cemeteries.] J@rgonia, Vol. 8, No. 17, pp. 1-25. Available at http://research.jyu.fi/jargonia/artikkelit/ jargonia17_ruohonen.pdf, last accessed on September 23, 2013.

Ruohonen, Juha 2011. A Witch's Coin from Tervo. In: J. Harjula \& M. Helamaa \& J. Haarala (eds.) Times, Things \& Places. 36 Essays for Jussi-Pekka Taavitsainen. Turku: J.P. Taavitsainen Festschrift Committee, pp. 344-357.

Rydving, Håkan 2004. Saami Religion and Saami Folk Religion. What is the Difference? Temenos, Vols. 39-40, pp. 143-149.

Saloranta, Elina 2010. Puurakentaminen ja puurakennukset Turussa 1300-luvulla. [Timber Constructions and Wooden Buildings in Turku in the 14th Century.] Turun museokeskus, Raportteja 22. Varhainen Turku, pp. 57-77.

Schiffer Michael B. 1987. Formation Processes of the Archaeological Record. Albuquerque: University of New Mexico Press.

Scribner, Robert W. 1993. The Reformation, Popular Magic, and the "Disenchantment of the World”. The Journal of Interdisciplinary History, Vol. 23, No. 3, pp. 475-494, http://dx.doi.org/10.2307/206099.

Stark, Laura 2002. Peasants, Pilgrims, and Sacred Promises. Ritual and the Supernatural in Orthodox Karelian Folk Religion. Studia Fennica Folkloristica, Vol. 11. Helsinki: SKS.

Stark, Laura 2006. The Magical Self: Body, Society and the Supernatural in Early Modern Rural Finland. FF Communications 290. Helsinki: Suomalainen tiedeakatemia.

Steadman, Sharon R. 2009. Archaeology of Religion. Cultures and Their Beliefs in Worldwide Context. California: Left Coast Press Inc. 
Suomen Kansan Muinaisia Taikoja (SKMT) I. Metsästys-taikoja 1891. [Hunting Magic 1891.] M. Varonen (ed.). Suomalaisen Kirjallisuuden Seuran Toimituksia 76. Helsinki: SKS.

Suomen Kansan Muinaisia Taikoja (SKMT) IV, 1. Karjataikoja 1933. [Livestock Magic 1933.] A.V. Rantasalo (ed.). Suomalaisen Kirjallisuuden Seuran Toimituksia 76. Helsinki: SKS.

Suomen Kansan Muinaisia Taikoja (SKMT) IV, 2. Karjataikoja 1933. [Livestock Magic 1933.] A.V. Rantasalo (ed.). Suomalaisen Kirjallisuuden Seuran Toimituksia 76. Helsinki: SKS.

Suomen Kansan Muinaisia Taikoja (SKMT) IV, 3. Karjataikoja 1934. [Livestock Magic 1934.] A.V. Rantasalo (ed.). Suomalaisen Kirjallisuuden Seuran Toimituksia 76. Helsinki: SKS.

Swann, June 2005. Interpreting Concealed Shoes and Associated Finds. In: I. Ericsson \& R. Atzbach (eds.) Depotfunde aus Gebäuden in Zentraleuropa - Concealed Finds from Buildings in Central Europe. Archäologische Quellen zum Mittelalter 2. Berlin: Scrîpvaz-Verlag, pp. 115-119.

Tarlow, Sarah 2011. Ritual, Belief and the Dead in Early Modern Britain and Ireland. New York: Cambridge University Press.

Väänänen, Kyösti 2000. Gadolin, Jacob (1719-1802). Kansallisbiografia-verkkojulkaisu. Studia Biographica 4. Helsinki: SKS. Available at http://www.kansallisbiografia. fi/kb/artikkeli/2260/, last accessed on September 23, 2013.

Väisänen, Maija 2000. Gadolin, Gustaf(1769-1843). Kansallisbiografia-verkkojulkaisu. Studia Biographica 4. Helsinki: SKS. Available at http://www.kansallisbiografia. fi/kb/artikkeli/3193/, last accessed on September 23, 2013.

Valk, Heiki 1995. The 13-17th Century Village Cemeteries of South Estonia in FolkTradition and Beliefs. Folk Belief Today. Tartu: Eesti Keele Instituut, Eesti Kirjandusmuuseum, pp. 501-509. Available at http://www.folklore.ee/rl/pubte/ ee/usund/fbt/valkh.pdf, last accessed on September 23, 2013.

Valk, Heiki 2004a. Artefacts in Estonian Urban Churchyards: Reflections on Different Traditions and Ideologies. In: D. Kattinger \& J.E. Olesen \& H. Wernicke (eds.) Der Ostseeraum und Kontinentaleuropa 1100-1600. Einflussnahme - Rezeption - Wandel. Schwerin: Thomas Helms Verlag, pp. 103-112.

Valk, Heiki 2004b. Christian and Non-Christian Holy Sites in Medieval Estonia: A Reflection of Ecclesiastical Attitudes towards Popular Religion. In: J. Staecker (ed.) The European Frontier. Clashes and Compromises in the Middle Ages. Lund: Almqvist \& Wiksell International, pp. 299-310.

Valk, Heiki 2006. Archaeology, Oral Tradition and Traditional Culture. In: V. Lang \& M. Laneman (eds.) Archaeological Research in Estonia 1865-2005. Tartu: Tartu University Press, pp. 311-316.

Valk, Heiki 2008. Offering Practices at Two Holy Stones in Setomaa, South-East Estonia. In: A.-B. Falk \& D.M. Kyritz (eds.) Folk Beliefs and Practice in Medieval Lives. BAR International Series 1757, pp. 67-78.

Vařeka, Pavel 1994. Customs and Rites Connected with the Building Process of a Rural House and its Importance for the Study of Archaic Notions about Space and 
Landscape. Mediaevalia Archaeologica Bohemica 1993, Památky archeologické, Supplementum 2, pp. 139-144.

Webb, Diana 2005. Domestic Space and Devotion in the Middle Ages. In: A. Spicer \& S. Hamilton (eds.) Defining the Holy. Sacred Space in Medieval and Early Modern Europe. Hants: Ashgate Publishing, pp. 27-47.

Whitehouse, Harvey 2004. Modes of Religiosity: A Cognitive Theory of Religious Transmission. Cognitive Science of Religion Series. Walnut Creek, CA: AltaMira Press.

Yoder, Don 1974. Toward a Definition of Folk Religion. Western Folklore, Vol. 33, No. 1. Symposium on Folk Religion, pp. 2-15, http://dx.doi.org/10.2307/1498248. 